\title{
The Link Between AACSB Accreditation And Graduate Schools
}

Teresa Hutchins, Ramapo College of New Jersey, USA

Alexandre Olbrecht, Ramapo College of New Jersey, USA

\begin{abstract}
In this paper, we examine whether graduating with a business or management degree from an AACSB Accredited school is correlated with higher or lower levels of graduate school attainment. We find that AACSB graduates are less likely to apply to graduate programs, and having done so, less likely to be accepted.
\end{abstract}

Keywords: AACSB, graduate education

\section{INTRODUCTION}

(2)

uring the past 20 years, many empirical studies have identified a growing trend in the disparity between the demand and supply of professors (for examples, see Bowen and Schuster, 1986, and Schapiro, O'Malley, and Litten, 1990). Most prominently, this trend has become a serious concern among business schools accredited by the Association to Advance Collegiate Schools of Business International. AACSB attributes the lower supply of new Ph.D.'s relative to open positions to three main factors: senior faculty that are retiring in larger numbers, an increase in demand for business degrees, and an insufficient enrollment in doctoral programs. ${ }^{1}$ In addition, AACSB's stringent guidelines for faculty qualifications make accredited business schools more selective when filling open positions.

As a response to the growing disparity, several academic studies have started to investigate the causes of this issue. Previous research can be divided into two areas: an analysis of institutional factors which seem to encourage enrollment in graduate programs and an analysis of the individual factors which seemingly motivate enrollment into graduate programs. In both cases, previous research has tended to focus on the one year time frame post undergraduate graduation.

In general, the intent this research is to provide policy makers with empirical data and to suggest ways to increase enrollment in graduate programs. It is the hope that upon graduation, a percentage of those students will enter the academic professions. As mentioned, the results of this research are of particular importance to the accrediting bodies of higher education institutions, especially AACSB. As a response to the shortage, AACSB has created "bridge programs" whose purpose it is to transform or re-educate individuals with selected non-business doctoral degrees and academically qualify those individuals to teach in accredited business schools. However, this response is a temporary remedy to an increasing problem which will need to be addressed.

In this paper, we use longitudinal data from the National Center for Education Statistics Baccalaureate and Beyond 93/97/03 survey and provide several innovations to differentiate ourselves from previous research. First, our time frame is the ten year period after college graduation. This allows us to identify students who take more than one year before beginning a graduate degree, a trend most prevalent for students pursuing graduate degrees in business. Second, we focus on the correlation between a specific type of accreditation, AACSB, and whether this factor is linked to the decision to apply to a graduate program. We do so because 559 accredited colleges and universities, and numerous other candidate programs are making significant monetary investments to achieve or maintain this

\footnotetext{
${ }^{1}$ As of June 2007 the overall vacancy rate among its surveyed member schools was 6.8 percent.
} 
accreditation. Given the number of students affected, it is imperative to understand the empirical impacts of AACSB accreditation.

\section{DATA AND ECONOMETRIC MODELS}

The data for this paper is taken from the Baccalaureate and Beyond Longitudinal Study, conducted by the National Center for Educational Statistics. It collected data focusing on the work and continuing education decisions of a cohort of 1993 college graduates. Essentially this survey provides a unique opportunity to assess the tradeoff between the work and education decisions of relatively recent college graduates. Other popular longitudinal surveys, such as the National Longitudinal Surveys of Youth or of specific high school classes focused on high school graduates, who have varying rates of college attendance and graduation.

In addition to the type of individuals included in this survey, the data used in this paper is the best available data because the survey collected very detailed information on each college graduate at several points in time, including the usual demographic, financial aid and employment/income information.

In this paper, we model two outcomes. First, we assess what empirical factors seemingly influence a person's decision as to whether or not to apply to a graduate school. Second, we identify factors which are correlated with an individual's acceptance into a graduate program. Intuitively one would expect that the decision to apply to a graduate program and whether or not he/she is accepted is a separate decision, which would be influenced by different factors or by similar factors differently. For example, an individual may be more inclined to apply to a graduate program due to a certain characteristic. However, admissions officers may have a track record which suggests that particular characteristic is not associated with successfully completing their program, and they would be more likely to reject that individual applicant because of that characteristic.

Ultimately, the two decisions are made by separate entities, and thus intuition would suggest that one should model these two decisions separately. Unfortunately, there are some well-known econometric dangers to doing so (see Montgomery and Anderson, 2007). The most visible danger posed by estimating two separate models is ignoring the effects of self-selection (for a good explanation of this issue, see Light and Strayer, 2002).

Therefore, to account for self-selection, we must concurrently model the decision to apply and be accepted to a graduate program. Given that our dependent variables in both equations are binary in nature, we are limited to employing a bivariate probit model with sample selection, where we first model whether an individual chooses to apply to at least one graduate program. This approach is consistent with the previous research of Shapiro, O'Malley and Litten (1991), Fox (1992), and Halbersstam and Redstone (2005).

The variable APPLIED takes a one value if the individual said they applied to at least one graduate program during the previous ten year period, and zero otherwise. The survey did not collect information on which programs an individual applied to and when they applied. The variable ACCEPT takes a one value if the person was accepted by a graduate school or not. The survey did not collect information on which schools accepted a particular individual.

We present the mean values of the major variables used in this study in Table I, and further divide the data into two cohorts: those who applied to at least one graduate program and those who did not. Hereafter the cohort who applied to at least one graduate school will be referred to as appliers. The latter cohort will be referred to as the non-appliers. Approximately two-thirds of respondents applied to at least one graduate school within ten years of college graduation.

Overall, there are some interesting differences between the two cohorts. As one might expect, the appliers have on average higher grades (3.25 as opposed to 3.10), and were more likely to have at least one parent with a graduate degree. An explanation for this observation maybe that parents with graduate degrees encouraged their offspring to pursue this type of higher education. It may also be the case that those students grew up in a household where they were exposed to the benefits of a graduate education. 
For completeness, we also include a variable which captures the highest quartile earned on any graduate entrance exam. We use this variable because of the many available options for standardized exams students have when applying to graduate programs.

Approximately 17 percent of the appliers received employer tuition reimbursement benefits, while almost none of the non-appliers did. This observed difference is in line with the human capital type explanation, which suggests that lowering the marginal cost to attending school for an individual will encourage that individual to invest in schooling and thus attain a greater stock of human capital (see Polachek and Siebert, 1996).

An additional financial distinction between the two cohorts is available when looking at the mean value of the amount of undergraduate debt held by graduates. The non-appliers have a smaller debt load on average, $\$ 5,671$ versus $\$ 13,496$. Intuitively one might think that individuals with larger debt loads would be less likely to further their educations. However, Shapiro, O'Malley and Litten (2001) found that undergraduate debt burdens had no statistical correlation with the decision to attend doctoral programs. Further, it may be that individuals with higher debt loads are more likely to borrow money because they view schooling as a good investment. Given these thoughts, it is not clear a priori how undergraduate debt will influence graduate schooling decisions.

When we model whether an individual is accepted by a graduate program, we would expect that graduate admissions directors take into consideration the rank of the undergraduate school attended by an individual, and in the case of a business program, whether the program was accredited by AACSB in 1993. To assess whether a program was accredited, we obtained a list of schools and their year of accreditation from AACSB International.

We define the variable AACSB very carefully. In order for an observation to be assigned a one value for AACSB, two factors must exist. First, an individual must have graduated with a business or management degree. Second, they must have graduated from a school which was accredited by AACSB in 1993. If both conditions were not met, the AACSB value was set to zero. For example, a chemistry major who graduated from a school accredited by AACSB would have been assigned a zero value for the AACSB variable. In this data, approximately four percent of appliers had earned an AACSB degree, while seven percent of non-appliers had earned this type of accredited degree.

In addition to controlling for AACSB accreditation, an adjustment needs to be made for the quality, or academic ranking, of the undergraduate school attended by any particular observation. Controlling for this attribute is a bit trickier since there are many different rankings variables available. In our case, we use the tier rankings provided by U.S. News and World Report for 1993 for schools located in the United States. ${ }^{2}$ In the survey provided by U.S. News and World Report, U.S. colleges and universities are divided into the categories of (1) the "Top 25 Schools" or best category, (2) schools in quartiles one through four, (3) regionally best schools, and (4) specialized schools.

For the select few undergraduate institutions located in Canada, the 1993 tier rankings provided by Maclean's Magazine were used. While the ranking criteria and scales used between the two magazines are slightly different (see Shale and Liu, 2002), in both cases they are the most appropriate and compatible measures available, given that we know of no survey which includes both Canadian and American schools.

In this paper, dummy variables for each of the tiers and groups were created. We choose these rankings because they are the most widely used and accepted by prospective students, employers, and by colleges and university administrations.

We also present demographic and occupational information for each cohort. As mentioned by Shapiro, O'Malley and Litten (1991), economists could argue that the inclusion and subsequent discussion of these types of variables could indicate different opportunity costs and the financial affordability of higher education for different

\footnotetext{
${ }^{2}$ While we know of no study that tests whether the type of rankings used will affect estimates in our type of regressions, Chang (YEAR) found that the type of ranking used did not matter when estimating earnings regressions. Further, U.S. News and World Report expanded their rankings after 1993.
} 
socio-economic groups. Sociologists could argue that differences across demographic cohorts could represent different social tradeoffs, costs and benefits. Since the aim of this paper is not to discuss the underlying reasons why factors may influence these types of academic decisions, we include these variables in our models for completeness and encourage other researchers to investigate the importance of the estimates for these particular independent variables. The occupation variables were coded directly from the survey.

\section{DISCUSSION OF RESULTS}

\section{A. Applied Regression}

We estimated our model using the bivariate probit approach with a selection correction first employed by Van de Ven and Van Pragg (1981). In our case, we treat the decisions on whether to accept an applicant by a graduate program and whether to apply as simultaneous decisions. Thus, our selection equation models whether an individual applied to at least one graduate program and our primary regression predicts acceptance to a graduate program. We present the estimates of our model in Table 2 and focus our discussion on the estimates for the AACSB variable, noting that the self-selection bias correction variable is marginally significant, indicating selfselection does not seem to be a major issue.

In both regression equations, the estimates for AACSB are significant and negative, indicating that AACSB graduates are less likely to apply to graduate programs and once having applied, less likely to be accepted. Upon first glance, these results may seem peculiar, however a relatively straightforward explanation does exist.

If one considers the basic premise of the human capital type models that individuals forgo earnings when making human capital investments, such as attending a graduate school, then economic theory postulates an individual will balance the marginal cost and marginal benefit of attending a graduate program. Therefore, one would expect individuals with higher earnings, ceteris paribus, to be less likely to take steps in pursuit of a graduate degree.

In the case of AACSB graduates, there exist several studies which suggest that AACSB graduates earn higher wages, all else constant. Kim et al. (1996) found that AACSB accounting graduates earned higher wages. More recently, Olbrecht and Yeaton (2008) found similar results for AACSB graduates in general. Olbrecht and Hutchins (2009) found that the wage premium for AACSB graduates was not dependent on the length of time a business school was accredited. Given this information, one could postulate that the reason we observe AACSB graduates are less likely to apply to graduate programs is that these individuals have higher opportunity costs.

There are also some other variables in our equations which address opportunity costs. For example, individuals with significant family obligations, like children or whether they are co-habiting with someone, are less likely to apply to graduate programs because they cannot afford to forgo earnings. Alternatively, our estimates suggest that individuals with tuition reimbursement plans are more likely to apply to graduate schools. If another economic agent is responsible for the cost of tuition, whether fully or partially, this serves to lower the marginal cost of going to a graduate program, and one would expect that individual to be more likely to apply.

However, an even more simple explanation exists for this outcome. It may be that individuals who choose to attend accredited business schools are individuals more interested in pursuing a business career and have relatively less interest in graduate school. It may also be that non-AACSB degree holders view greater nonpecuniary effects in graduate education. In other words, AACSB degree holders may receive less utility from an education, and thus would be more likely to remain in the workforce.

\section{B. Accepted Regression}

The significant and negative estimate on AACSB in the second regression implies that AACSB graduates are less likely to be accepted into at least one graduate program. We can extend our analysis of the first regression in order to provide an explanation for this outcome. Specifically, if graduate admissions officers believe that there is an opportunity cost for AACSB graduates in terms of higher lost wages, then individuals with an AACSB degree who 
apply to graduate programs are identifying themselves as those individuals with the lowest opportunity costs. In other words, those AACSB graduates will be identifying themselves as weaker than their peers. It then would naturally follow for graduate admissions officers to be more hesitant in accepting those individuals.

Another plausible explanation could be that AACSB graduates are more likely to apply to highly competitive graduate programs with lower acceptance rates. If this is true, then one would expect the coefficient to be significant and negative for the AACSB variable. Once again, had we been able to identify to which school(s) applicants applied to in the data, we could decipher which explanation is more suitable to explain the estimate for AACSB.

However, there may be some anecdotal evidence in the data which suggests the quality argument is more valid. The control variables for the upper tier rankings of the undergraduate programs are also negative and significant, suggesting that individuals from higher ranked schools are less likely to be accepted into graduate programs. The only reasonable explanation for this outcome is that those graduates are attempting to enter the most competitive programs.

\section{Other Results}

For completeness, we also comment on some of the other estimates in our model. The two variables which measure academic preparation, GPA and test quartile, both have positive and significant estimates in both equations. While these estimates make intuitive sense, Halberstam and Redstone (2005) found that these variables have no predictive power on the grades of students once enrolled in graduate programs.

We also find that male students are more likely to be accepted into graduate schools. One explanation is that given the limited number of seats available, schools will be encouraged to accept men because they have higher graduation rates from graduate programs than women. Montgomery and Anderson (2007) document this outcome and suggest that family obligations may only be a partial explanation for the lower rates of graduation for women.

Finally, the coefficients for the higher ranked schooling variables in the first equation are positive and significant, indicating that graduates from better schools are more likely to apply to graduate schools. These results are similar to that of Shapiro, O'Malley and Litten (1991).

\section{CONCLUSION}

In this paper, we focused on the correlation between AACSB accreditation and the decision on whether to apply to graduate programs for a group of 1993 college graduates. Our results are consistent with the economic theory which postulates that individuals compare the discounted present value of the future benefits of a graduate education with the marginal cost to attend, and the greater the marginal cost, the less likely individuals are to undertake investments in human capital.

AACSB argues its standards ensure that accredited business schools will graduate individuals with the skills necessary to enrich their lives and make meaningful contributions to corporate organizations (see the report by the AACSB International Task Force on Issues in Management Education, 2005). Ultimately, these types of graduates should earn higher wages, and thus face higher marginal costs when deciding to attend graduate programs.

In our paper, we have found empirical evidence that AACSB graduates are less likely to apply for graduate admissions and subsequently, be less likely to be accepted. Our results suggest that AACSB is fulfilling its stated mission to effectively prepare its graduates to be successful in the business world. In a particularly strange twist of fate, it seems that by doing so, AACSB has made it more expensive for its graduates to attend graduate school, and thus indirectly may be contributing to the faculty shortage it is trying to correct.

\section{ACKNOWLEDGEMENT}

The authors would like to thank the National Center for Education Statistics and The Association to Advance Collegiate Schools of Business (AACSB International) for providing the data, and Ramapo College of 
New Jersey for institutional support. We would also like to thank the participants at the Eastern Economics Association Annual Meetings in new York for valuable comments. This research was made possible by a generous grant from Richard Anisfield.

\section{AUTHOR INFORMATION}

Alexandre Olbrecht is an assistant professor of economics at the Anisfield School of Business at Ramapo College of New Jersey and a research associate at the State University of New York at Binghamton.

Teresa Hutchins is an assistant professor of economics and director of the economics program at the Anisfield School of Business at Ramapo College of New Jersey.

\section{REFERENCES}

1. AACSB International Task Force on Issues in Management Education. 2005. Why Management Education Matters: Its Impact on Individuals, Organizations, and Society, Tampa, Florida.

2. Bowen, H.R., and J. H. Schuster. 1986. American Professors: A National Resource Imperiled. New York: Oxford University Press.

3. Fox, M. 1992. Student Debt and Enrollment in Graduate and Professional School. Applied Economics 24: 669-677.

4. Halbersstam, B., and F. Redstone. 2005. The Predictive Value of Admissions Materials on Objective and Subjective Measures of Graduate School Performance in Speech-Language Pathology. Journal of Higher Education Policy and Management 27: 261-272.

5. Heckman, J. J. Jan. 1979. Sample Selection Bias as a Specification Error. Econometrica 47: 153-161.

6. Kim, K., J. Rhim, W. Henderson, N. Bizal, and G. Pitman.1996. AACSB accreditation: A positive signal in accounting job markets. Mid-Atlantic Journal of Business 32: 123-134.

7. Maclean's Magazine College Rankings, Nov. 15, 1993.

8. Marts, J. R., J. D. Baker, and J. M. Garris. 1988. Success on the CPA examination in AACSB accredited and non-accredited schools. Accounting Educators' Journal 1: 74-91.

9. McPherson, M. and M. O. Shapiro. 1991. Does Student Aid Affect Enrollment? New Evidence on a Persistent Controversy. The American Economic Review 81: 309-318.

10. Mongomery, M., and K. Anderson. 2007. Best Laid Plans: Gender and the MBA Completion Rates of GMAT Registrants. The Quarterly Review of Economics and Finance 47: 175-191.

11. Morse, R. J. and S. Flanigan. 2007. How We Do the Rankings. U.S. News and World Report America's Best Colleges 77-79.

12. National Center for Education Statistics (NCES). 1993. Integrated Postsecondary Education Data System 'Completions' and 'Consolidated' surveys.

13. Olbrecht, A. and T. Hutchins. 2009. AACSB International Accreditation and the Earnings of College Graduates, The American Journal of Business Education, 2 (1), January/February, 117-124.

14. Olbrecht, A., and K. Yeaton. 2008. The Value of Undergraduate AACSB Accreditation on the Earnings of College Graduates. Unpublished paper, Ramapo College of New Jersey.

15. Polachek, S. and W. S. Siebert. 1993. The Economics of Earnings. New York: Cambridge University Press.

16. Shale, D. and Y. Liu. 2002. Ranking the Rankers of Universities: Canada's Maclean's Magazine versus U.S. News \& World Report. Unpublished paper, University of Calgary.

17. Shapiro, M. O., M. O’Malley, and L. Litten. 1991. Progression to Graduate School from the "Elite" Colleges and Universities. Economics of Education Review 10: 227-244.

18. U.S. News \& World Report (1993). College Rankings 115 (13), Oct. 4.

19. Willis, R. J., and S. Rosen. 1979. Education and Self-Selection. Journal of Political Economy 87: S7-36.

20. Van de Ven, W. P., and B. M. Van Pragg. 1981. The Demand for Deductibles in Private Health Insurance: A Probit Model with Sample Selection. Journal of Econometrics 17: 229-252.

21. Zhang, L. 2005. Do Measures of College Quality Matter? The Effect of College Quality on Graduates' Earnings. The Review of Higher Education 28: 571-596. 
Table One: Variable Means by Cohort

\begin{tabular}{|c|c|c|c|c|c|c|}
\hline \multirow[b]{2}{*}{ Variable } & \multicolumn{2}{|l|}{ Full Sample } & \multicolumn{2}{|l|}{ Applied $=1$} & \multicolumn{2}{|l|}{ Applied $=0$} \\
\hline & Mean & Std. Dev. & Mean & Std. Dev. & Mean & Std. Dev. \\
\hline Applied to at least one graduate program (APPLIED) & 0.66 & 0.47 & 1.00 & 0.00 & 0.00 & 0.00 \\
\hline $\begin{array}{l}\text { Accepted to at least one graduate program } \\
\text { (ACCEPTED) }\end{array}$ & 0.30 & 0.46 & 0.45 & 0.50 & 0.00 & 0.00 \\
\hline Earned an AACSB degree & 0.05 & 0.22 & 0.04 & 0.19 & 0.08 & 0.27 \\
\hline Undergraduate Debt & $\$ 10,842.59$ & $19,063.81$ & $\$ 13,496.27$ & $22,186.10$ & $\$ 5,671.29$ & $8,487.00$ \\
\hline Undergraduate GPA (4.0 scale) & 3.20 & 0.45 & 3.26 & 0.44 & 3.10 & 0.46 \\
\hline Test Quartile & 0.55 & 1.16 & 0.79 & 1.33 & 0.08 & 0.51 \\
\hline Parent earned a graduate degree & 0.27 & 0.44 & 0.30 & 0.46 & 0.21 & 0.40 \\
\hline Male & 0.43 & 0.50 & 0.42 & 0.49 & 0.45 & 0.50 \\
\hline Caucasian & 0.85 & 0.36 & 0.83 & 0.37 & 0.87 & 0.34 \\
\hline Married or Co-Habiting with a partner & 0.73 & 0.45 & 0.71 & 0.45 & 0.76 & 0.43 \\
\hline Number of Children (in 2003) & 1.05 & 1.19 & 0.97 & 1.15 & 1.20 & 1.25 \\
\hline Employer reimbursed tuition (1 if yes) & 0.12 & 0.32 & 0.18 & 0.38 & 0.001 & 0.04 \\
\hline Attended Best Ranked School & 0.07 & 0.26 & 0.10 & 0.29 & 0.03 & 0.16 \\
\hline Attended Tier One School & 0.08 & 0.27 & 0.09 & 0.28 & 0.05 & 0.22 \\
\hline Attended Tier Two School & 0.14 & 0.35 & 0.15 & 0.36 & 0.13 & 0.33 \\
\hline Attended Tier Three School & 0.11 & 0.31 & 0.11 & 0.31 & 0.12 & 0.33 \\
\hline Attended Tier Four School & 0.08 & 0.27 & 0.08 & 0.26 & 0.08 & 0.27 \\
\hline Number of Observations & 11,270 & & 7,450 & & 3,820 & \\
\hline
\end{tabular}

Number of Observations

* Occupation Categorical Variable Values are available upon request.

** All sample sizes are rounded to the nearest tenth, as required by the NCES. 
Table Two: Regression Results

\begin{tabular}{|c|c|c|c|c|}
\hline & Variable & Coef. & $\mathrm{Z}$ & $\mathrm{P}>|\mathrm{z}|$ \\
\hline \multicolumn{5}{|l|}{ Accepted } \\
\hline & Earned an AACSB degree & -0.324 & -4.010 & 0.000 \\
\hline & Male & 0.070 & 2.270 & 0.023 \\
\hline & Caucasian & -0.122 & -2.950 & 0.003 \\
\hline & Attended Best Ranked School & -0.289 & -4.970 & 0.000 \\
\hline & Attended Tier One School & -0.157 & -2.670 & 0.008 \\
\hline & Attended Tier Two School & -0.033 & -0.720 & 0.474 \\
\hline & Attended Tier Three School & -0.091 & -1.760 & 0.079 \\
\hline & Attended Tier Four School & 0.082 & 1.410 & 0.159 \\
\hline & Test Quartile & 0.281 & 21.760 & 0.000 \\
\hline & Undergraduate GPA (4.0 scale) & 0.363 & 9.930 & 0.000 \\
\hline & Constant & -1.429 & -11.030 & 0.000 \\
\hline \multicolumn{5}{|l|}{ Applied } \\
\hline & Earned an AACSB degree & -0.237 & -3.850 & 0.000 \\
\hline & Undergraduate Debt & 0.00022 & 15.600 & 0.000 \\
\hline & Parent earned a graduate degree & 0.273 & 8.120 & 0.000 \\
\hline & Undergrad GPA (4.0 scale) & 0.404 & 12.660 & 0.000 \\
\hline & Attended Best Ranked School & 0.774 & 11.130 & 0.000 \\
\hline & Attended Tier One School & 0.427 & 7.430 & 0.000 \\
\hline & Attended Tier Two School & 0.314 & 7.340 & 0.000 \\
\hline & Attended Tier Three School & 0.108 & 2.400 & 0.017 \\
\hline & Attended Tier Four School & 0.147 & 2.740 & 0.006 \\
\hline & Male & 0.137 & 4.550 & 0.000 \\
\hline & Caucasian & -0.254 & -6.280 & 0.000 \\
\hline & Married or Co-Habiting with a partner & -0.111 & -3.320 & 0.001 \\
\hline & Number of Children (in 2003) & -0.097 & -7.790 & 0.000 \\
\hline & Employer reimbursed tuition (1 if yes) & 2.706 & 15.470 & 0.000 \\
\hline & Constant & -1.400 & -11.590 & 0.000 \\
\hline & Rho & 0.063 & 1.370 & 0.169 \\
\hline & Number of Observations & 11,270 & & \\
\hline & Prob $>$ Chisq & 0.000 & & \\
\hline
\end{tabular}

